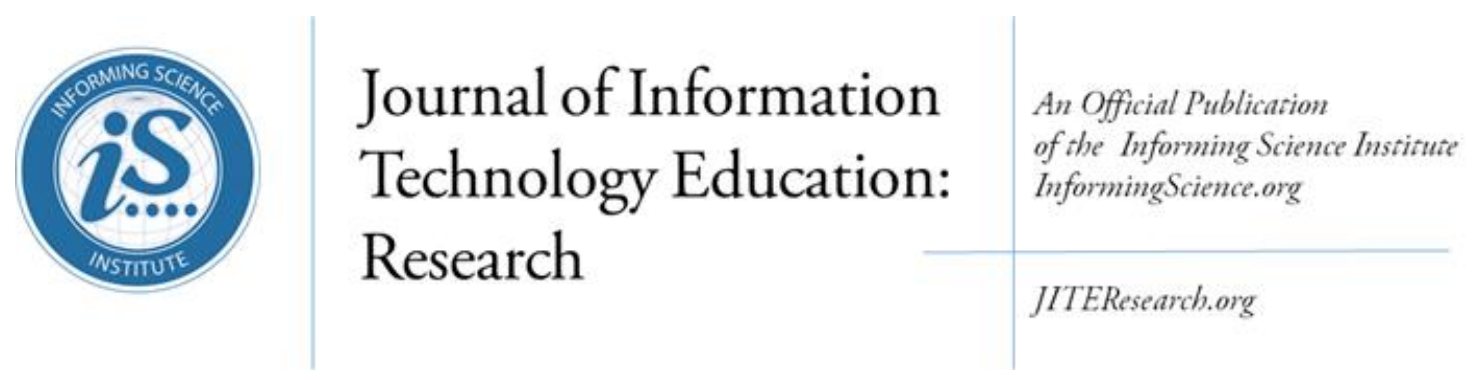

Volume 20, 2021

\title{
TEACHER-STUDENT INTERACTION IN DISTANCE LEARNING IN EMERGENCY SITUATIONS
}

\author{
Hava Sason* \\ Avichai Kellerman \\ *Corresponding Author
}

Herzog Academic College, Jerusalem, Israel

Herzog Academic College, Jerusalem, Israel

havasason@gmail.com

avichai@herzog.ac.il

\section{ABSTRACT}

Aim/Purpose

The goal of this study was to examine which of the types of teacher-student interactions found in previous studies by Kang (2009) and Kang and Im (2013) during distance learning in routine situations, were also found in times of emergency, specifically during the COVID-19 pandemic, and whether these interactions differed between students with regard to the extent and nature of each type of interaction.

Background

Teacher-student interactions during learning in general and particularly in distance learning has an impact on students' satisfaction, motivation, and ability to contend with learning assignments. As learning in times of emergency poses additional, unique challenges, teacher-student interactions may be affected as well.

Methodology

The participants in the study were 591 undergraduate students from different departments in a teaching college, who answered an opinion survey after completing a semester of distance learning due to the COVID-19 pandemic. Qualitative textual content analysis was performed on students' answers to openended questions about the nature of their interaction with their teachers. The students' answers were divided and analyzed according to the answers they gave on a separate questionnaire on self-regulation in learning.

Contribution

The findings of this study can offer a theoretical contribution to understanding the different types of teacher-student interactions in distance learning in emergency situations, their frequency, and how they are connected to students' selfregulation. From the practical perspective, the study highlights the importance of this interaction, especially in times of emergency, and offers practical insights for teachers in academia and in general.

Accepting Editor Dennis Kira | Received: August 11, 2021 | Revised: October 24, November 14, 2021 | Accepted: November 30, 2021.

Cite as: Sason, H., \& Kellerman, A. (2021). Teacher-student interaction in distance learning in emergency situations. Journal of Information Technology Education: Research, 20, 479-501. https://doi.org/10.28945/4884

(CC BY-NC 4.0) This article is licensed to you under a Creative Commons Attribution-NonCommercial 4.0 International License. When you copy and redistribute this paper in full or in part, you need to provide proper attribution to it to ensure that others can later locate this work (and to ensure that others do not accuse you of plagiarism). You may (and we encourage you to) adapt, remix, transform, and build upon the material for any non-commercial purposes. This license does not permit you to use this material for commercial purposes. 
Findings

Recommendations for Practitioners

Recommendations for Researchers

Impact on Society

Future Research

Keywords
The study's findings reflect students' critical need for interaction with their teachers in emergency distance learning. The students reported different types of interaction with their teachers during the COVID-19 period. The most common form of interaction was instructional communication (Q\&A), which mainly took place via email, though students would have preferred WhatsApp. The least common form of interaction was social intimacy. Students with a high level of self-regulation were more likely to report on interaction with the teacher, and to take more responsibility for whether or not interaction occurred.

Considering the findings of this study, colleges and universities should invest in training and encouraging teachers to engage in different types of interaction with their students. It is important for teachers to be aware of the need for these types of interaction. Encouraging teacher-student interaction in teachers' training colleges (where this study was carried out) is also important, as it may affect the teaching methods used by the students when they become teachers in the future and, consequently, influence the entire education system.

Research of teacher-student interaction in distance learning should take into account the unique characteristics and challenges posed by this type of learning in times of emergency, as found in this study. Additional technological and pedagogic tools should be developed to improve teacher-student interaction so that it meets the students' expectations during routine and emergency times alike.

Studies have found that teacher-student interaction is one of the greatest contributors to students' motivation and satisfaction and to their ability to cope with learning assignments. As distance learning has become widespread and inevitable in times of emergency or crisis, which may occur again in the future, improving interaction during distance learning in an emergency is very important. This may improve the learners' ability to maintain their regular learning routine despite the emergency situation.

It is recommended to expand the research method and examine the data using in-depth interviews and questionnaires. It is also worth comparing the findings of this study with findings of similar studies among students in colleges and universities other than teachers' training colleges, graduate students, and students of different ages.

emergency remote teaching (ERT), teacher-student interaction, self-regulated learning (SRL)

\section{INTRODUCTION}

The COVID-19 pandemic that swept through the world as this paper was written highlighted the critical need for distance learning (Brady \& Pradhan, 2020). The health risk forced universities and colleges to transition to distance teaching within just a few days, without advance warning and without sufficient time to prepare in an orderly way (Crawford et al., 2020; Lipsitch et al., 2020). The teaching and learning methods changed, and various technological platforms, course websites, and digital tools for distance learning were utilized (Altbach \& De Wit, 2020). Studies refer to this as emergency remote teaching (ERT) (Hodges et al., 2020). Remote teaching naturally changed the interaction between teachers and students, which is generally based on face-to-face meetings on the educational institution's campus. Teachers and students had to adopt new ways of communicating and interacting with each other in order to carry out and advance learning (Adnan \& Anwar, 2020; Khalil et al., 2020). This study deals with teacher-student interaction in distance learning in times of emergency. The participants were BA students at a teachers' training college who studied from a distance during the pandemic. The study used qualitative analysis of statements in students' responses to 
examine which types of interaction that were found in previous studies to be used in routine situations (Kang, 2009; Kang \& Im, 2013) are also utilized in emergencies; which are more common than others; and whether there is a connection between the student's level of self-regulated learning and the types of interactions reported. The study sheds light on students' perceptions of their interactions with their teachers during the pandemic, given the significant role this interaction plays in learning in general (Ahmad et al., 2017; Javid et al., 2013; Maulana et al ,2014) and in distance learning in routine times (Brenton, 2014; Sher, 2009; Wright et al., 2015), taking into consideration the students' expectations for optimal interactions in emergency situations as well (Adnan \& Anwar, 2020; Khalil et al., 2020).

The contribution of this study is towards raising awareness among teachers and institutions of higher education of these perceptions, in order to address students' needs and improve teaching in emergency situations.

\section{EMERGENCY REMOTE TEACHING}

Emergency remote teaching (ERT) shares several characteristics with distance learning in routine times, such as scheduling and flexible locations (Stone et al., 2019), accessibility (Stone et al., 2019), and opportunities for cooperation and sharing information between groups of learners from different place and cultures (Donitsa-Schmidt, \& Topaz, 2018). They also share similar challenges, such as difficulties encountered by students and teachers when attempting to navigate technological platforms, internet connection problems (Allen \& Seaman, 2013; Almuraqab, 2020; Bozkurt \& Sharma, 2020), challenges related to the absence of a classroom environment in which the teacher's body language, eye contact, and teacher-student gestures play a significant role (Hodges \& Fowler, 2020), a sense of loneliness (Weller, 2007), and difficulties with independent learning with a teacher's close guidance (K. Lee et al., 2019).

ERT has several unique characteristics and challenges that can impact the learning method, teaching methods, and student-teacher interactions. Routine distance learning is prepared far in advance. In many cases, several months are invested in preparing the course. In the case of ERT, these preparations must be made much faster. This can affect the quality of the course and make it difficult for teachers to develop a learning environment that facilitates interaction and meticulous support for the students (Bozkurt, \& Sharma, 2020; Mohammed et al., 2020).

During routine distance learning, technological support is more readily available than in times of emergency, when the number of students and teachers who attend these courses is much larger. According to Schlesselman (2020), during a crisis, the support teams cannot provide adequate support to all the faculty members and students because of the many requests they receive and the pressure they are under.

Emergency situations can also pose challenges in the home and family settings. If schools are closed, children are home and can interfere with the students' learning. Many families often lack the digital infrastructure needed for all its members who need it for distance learning. This can interfere with students' attendance in their courses and their availability for learning and can increase their need for interaction with the teacher to complete the requirements of the course (Almuraqab, 2020; Hodges \& Fowler, 2020).

Another difference between ERT and routine distance learning is that the latter is generally offered in addition to on-campus learning for those who are interested and not as the exclusive learning method for all (Hodges et al., 2020). During the COVID-19 pandemic, the entire system was forced to transition to online platforms that were not well-suited for all students. The result was a greater need for support than in routine situations and for more intensive interaction with the teacher (Adnan \& Anwar, 2020; Heo \& Han, 2020; Lazarevic \& Bentz, 2021). In order to succeed, students needed their teachers' assistance and guidance as they transitioned to a more independent style of learning once face-to-face classroom interaction became unavailable (Carter et al., 2020). The new situation 
Teacher-Student Interaction in Distance Learning in Emergency Situations

highlighted the importance of self-direction, which has been shown to be a crucial and fundamental part of learning (Pintrich, 2000, 2004; Zimmerman, 2001, 2008), particularly when learning from a distance (Carter et al., 2020; Naujoks et al., 2021; Samruayruen et al., 2013; Tsai, 2010).

\section{SELF-REGULATED LEARNING}

Self-regulated learning (SRL) refers to the metacognitive, motivational, and behavioral elements that indicate that the learner is an active participant in the learning process (Butler \& Cartier, 2005; Pintrich, 2000, 2004; Schraw, 2006; Zimmerman, 2001, 2008). These processes are what cause learners to invest their thoughts, emotions, and actions in improving their performance and achieving their learning goals. Learners initiate and utilize a variety of self-regulation strategies, such as planning how to use available resources like time and learning materials, choosing suitable strategies, adapting their goals, and formulating plans based on feedback they give themselves or receive from their teachers or others. This requires them to acknowledge and assess their own abilities (Pintrich, 2000; Zimmerman, 2001). Studies maintain that the greater the learners' self-regulation, the higher their academic achievements (Pajares \& Schunk, 2002; Puzziferro, 2008; Zimmerman, 2002), and studies on distance learning have shown that self-regulation is the main contributor to students' success and satisfaction with online courses (Jansen et al., 2017; Kocdar et al., 2018; C. Lee, 2015).

Studies claim that when learning takes place in an online environment, self-regulation in learning becomes even more crucial (Greene et al., 2018; T. H. Lee et al., 2008; Tsai, 2010). Students must manage, regulate, and supervise their learning and motivation more independently than in the classroom setting (Conard \& Donaldson, 2012; Leasure et al., 2000; Samruayruen et al., 2013). Greene et al. (2018) found that the more students employ self-regulation strategies, the more successful they are at developing online learning skills. Similarly, Kiliç-Çakmak (2010) found that use of internal resource management strategies predicted the students' ability to assess and communicate information during distance learning. Considering the added challenges posed by learning during the COVID-19 pandemic, learning management and regulation became even more complicated. Students were forced to organize physical space in their homes and adapt it for learning, while avoiding distractions. They had to be flexible and regulate learning differently, in light of the frequent, unexpected changes they encountered, such as the transition from written material and lectures to digital teaching platforms. They had to find new ways of communicating with their peers and teachers when they needed assistance and manage and regulate communication with them in a different and more independent way to achieve the learning goals (Adnan \& Anwar, 2020; Carter et al., 2020; Naujoks, 2021). Studies dealing with distance learning show that teachers can improve the student's self-regulation with appropriate interaction (Artino, 2007; Cho \& Shen, 2013; Cole et al., 2017; Samruayruen et al., 2013).

\section{TEACHER-STUDENT INTERACTION IN DISTANCE LEARNING}

Teacher-student interaction is one of the main parameters for influencing students' success in learning. This interaction has been linked to better management in classrooms (M. Murphy \& Valdéz, 2005; Pianta, et al., 2012), students' commitment to learning (Ahmad et al., 2017; L. C. Strauss \& Volkwein, 2004), greater effort on the part of the students (Lundberg \& Schreiner, 2004), higher motivation (Eccles, 2004), students' satisfaction (Calvo et al., 2010; Trigwell, 2005), active involvement in learning (Eccles, 2004, Rugutt \& Chemosit, 2009), and improved learning outcomes (Frymier, 2007; Javid et al., 2013: Maulana, et al., 2014; Wright et al., 2015). Studies have also shown that interaction plays an important role in students' decisions about whether to complete their studies or drop out after the first year (Wilcox et al., 2005). It also seems that the more interactions students have with their teachers outside the classroom setting, the better the quality of the interaction (Hagenauer \& Volet, 2014), although the frequency of interactions cannot always determine the quality of the interactions or of the basic relationship formed (Dobransky \& Frymier 2004; Komarraju et al., 2010).

Studies that deal with online learning showed the contribution of teacher-student interaction to effective learning and academic success in distance learning (Kim et al., 2005; Pallof \& Pratt, 2001; 
Sher, 2009). In standard learning situations, most teacher-student interaction occurs in the classroom, whereas in distance learning interaction occurs by email, WhatsApp, in synchronous sessions, etc. (Brady \& Pradhan, 2020; Hodges et al., 2020). According to several studies, this makes interaction more complex (Brenton, 2014; Sher, 2009; Wright et al., 2015). For example, many of the verbal and nonverbal cues that support the development of relationships in traditional face-to-face encounters, such as body language, intonation of speech, and facial expressions, do not exist in distance learning situations (E. Murphy \& Rodríguez-Manzanares, 2012; Wright et al., 2015). Sher (2009) explained that in a traditional classroom environment, students' facial expressions allude to their understanding of the material. However, in an online environment, it is difficult for teachers to perceive that their students are confused or do not understand, unless the students specifically choose to communicate and ask questions. Brenton (2014) also maintained that the absence of face-to-face interaction poses challenges that may affect students' motivation for learning, which can make distance learning less effective than classroom learning.

Studies have found that learners who reported greater interaction with their teachers also reported greater satisfaction (Burnett et al., 2007; Collison et al., 2000; Kang \& Im, 2013; Sher, 2009). For example, Burnett et al. (2007) explored three dimensions of interaction - frequency, intensity, and topicality - by examining chat logs and discussion board postings from eight online Information Studies graduate courses and interviewing a focus group of students. They found that the greater the frequency and intensity of interaction, the more likely the student would be to express greater satisfaction with the course. Although many studies on distance learning showed the contribution of the teacher-student interaction to effective learning and academic success (Kim et al., 2005; Pallof \& Pratt, 2001; Sher, 2009), Su et al. (2005) found that students have differing perceptions of the importance of online interactions and of the types of interactions required. The researchers explained that the different perceptions may be related to differences in students' personalities and learning styles.

Given the importance of teacher-student interaction and the need to accommodate the needs and expectations of different students, when courses are taught from a distance teachers should find new ways of connecting with their students and develop new communication methods that are well-suited for synchronous and asynchronous distance learning environments. Studies suggested that online technology such as email, chat rooms, synchronous meetings, and discussion forums can improve interaction (Sher, 2009). A study by Khalil et al. (2020) found that during the COVID-19 pandemic, the lack of non-verbal communication between teachers and students was described as one of the main challenges for students. One student said that:

Even though, I managed to cope up with online teaching but I desperately missed body language like eye-to-eye contact with instructors. ... I missed active, interactive sessions like team-based learning sessions, peer instruction skills, and discussions among students. I prefer to study within campus ambit. (p .6)

Another study from the COVID-19 period in India (Nambiar, 2020) found that one of the most important factors for student satisfaction with distance learning was quality and timely interaction between students and professors. Students of higher education in Pakistan also described the importance of interaction with their professors during the COVID-19 pandemic, as presented in a study by Adnan \& Anwar (2020). They noted that students highlighted the importance of timely responses from their instructors, and that $78.6 \%$ of the students reported that interacting with the instructor can improve learning effectiveness in distance learning in times of emergency. According to Hagenauer \&Volet (2014), very little is known about how interactions are perceived, assessed, and attempted by students and instructors. They wrote that there is a need for further research to explore and define the importance of different types of teacher-student interactions, as different types of interactions have different value and relevance. 


\section{TYPES OF TEACHER-STUDENT INTERACTION}

Studies have attempted to characterize the various types of interaction between teachers and students that are necessary for effective learning, Hagenauer and Volet (2014) defined two main dimensions of the teacher-student interaction. One is the affective dimension, which describes the bond built between students and teachers, forming the basis for secure, effective, positive-experienced relationships. The second is the support dimension, which describes the support that must be provided to facilitate students' success at university (e.g., teachers setting clear expectation, answering emails promptly). Reupert et al. (2009) emphasized the first dimension, the affective dimension. Based on their findings, they showed that in online courses a large majority of students expect interpersonal communication and emotional involvement from their teachers. They maintained that students expect teachers in digital courses to pay them more personal attention, express emotions, be open and humorous, and provide personal feedback. These findings were supported by Garrison (2011) and by Jung et al. (2002), who also found that this type of interaction can contribute to the students' achievements. A study by Deci and Ryan (2012) confirmed that this is a basic need of the student and explained that an environment that is supportive of the learner's basic psychological needs can contribute to the internalization of values, behaviors, and beliefs and can yield motivation that improves the student's self-regulation when learning.

However, other studies show that interpersonal relationships between students and their university instructors must maintain a balance and not exceed a certain threshold. Hagenauer \& Volet (2014) wrote that this relationship "is considered one that must be balanced" (p. 377). Sibii (2010) also described the role of the teacher in these relationships as "being a friendly individual, but not a friend" (p. 531). Holmes et al. (1999) discussed the risks of a relationship that is too close and too informal, which they believed may be dangerous for university students and instructors alike, who have a hierarchal relationship by nature that entails a certain division of power. Their study showed that when teachers' behavior exceeded their academic roles, students found it inappropriate.

Studies that focused on interaction related to the learning material itself showed that ongoing evaluation of the students' performance and immediate feedback, combined with individual assistance, helps students succeed in distance learning (Cole et al., 2017; Swan, 2003). According to Lehman and Conceição (2010), interaction based on the teacher's assistance with the subject matter helps improve students' meta-cognitive thinking. Hara and Kling (2001) interviewed students who reported feeling confused, anxious, and frustrated when their instructor did not provide quick, clear feedback and when the instructions they received were obscure. Quick responses to students' questions about the learning material improved students' self-confidence (Cole et al., 2017), motivation (Gelbart, 2000), and self-efficacy (Harlen, 2006). Some scholars, such as Zhou et al. (2008), noted that teacher-student interaction is context-dependent. They showed that students from different countries have different expectations of their interactions with their instructors. Sander et al. (2000) claimed that the subject matter influences students' perceptions about their interactions with their teachers.

Kang (2009), who researched learners' perceptions of interactions with teachers, collected data from 895 students from five universities in which studies took place online and used the data to develop a model that includes five types of interaction: instructional communication (Q\&A), guiding and facilitating learning, social intimacy, instructional support, and presence of the instructor.

Instructional communication refers to communication between the learner and the teacher about topics connected directly to the subject matter (using questions and answers). Guiding and facilitating learning refers to how learning activities are led (not directly connected to the subject matter). Social intimacy refers to interaction in which the teacher and learner share personal information (not directly connected to the subject matter). Instructional support refers to how the teaching process is managed, including supportive learning materials provided and feedback that is directly connected to the course content. Presence of the instructor refers to how the students perceive their teacher's presence in the distance learning environment. 
Kang and Im (2013) explored which of the types of interaction in Kang's study (2009) can predict learners' perceived scholastic achievements and their satisfaction with distance learning environments. Their study showed that factors related to instructional communication and presence of the instructor can predict learners' satisfaction. Instructional communication also significantly predicted learners' achievements. This advantage of instructional communication was also found in studies by Fredericksen et al. (2000) and Swan et al. (2000). On the other hand, Kang and Im (2013) found that social intimacy had a negative correlation with students' learning achievements and their satisfaction with the course.

The current study examines which of the types of interaction identified by Kang (2009) and Kang and $\operatorname{Im}(2013)$ are also demonstrated in an emergency situation, and specifically during the COVID19 pandemic, and which of these types of interaction are most common. It also explores whether there is a connection between this type of interaction and the students' level of self-regulated learning.

\section{METHOD}

\section{PARTICIPANTS}

The participants in the study were 591 undergraduate students from different departments (education, special education, mathematics, science, geography, history, civil studies, bible studies, English, linguistics, and communication) in one teaching college, out of 1300 students who received the survey. The participants were 204 men (35\%) and 387 women (65\%), and the average age was 25.67.

The Table 1 groups the participants by year of study and gender.

Table 1 - The participants' year of study and gender

\begin{tabular}{|l|l|l|l|l|l|}
\hline Year & Men & Women & $\begin{array}{l}\text { Percentage } \\
\text { men }\end{array}$ & $\begin{array}{l}\text { Percentage } \\
\text { women }\end{array}$ & Total \\
\hline 1 & 68 & 133 & $34 \%$ & $66 \%$ & 201 \\
\hline 2 & 53 & 117 & $31 \%$ & $69 \%$ & 170 \\
\hline 3 & 52 & 96 & $35 \%$ & $65 \%$ & 148 \\
\hline 4 & 31 & 41 & $43 \%$ & $57 \%$ & 72 \\
\hline Total & 204 & 387 & $35 \%$ & $65 \%$ & 591 \\
\hline
\end{tabular}

The participants all belonged to a predefined group of BA students studying education at the same institution of higher education, who had learned from a distance during an emergency situation after learning in a standard face-to-face setting beforehand and, therefore, could describe the advantages and disadvantages of their interactions with their instructors during the emergency period.

\section{PROCEDURE AND TOOLS}

The survey was carried out at the end of 2020 after one semester of distance learning during the COVID-19 pandemic, in which classes took place synchronously on Zoom and some were accompanied by asynchronous tasks or recordings. The goal of the survey was to examine the students' views on distance learning. The survey was available on the internet for two weeks, during which participants could anonymously enter their answers. All participation was voluntary. The participants were aware that the survey would be used to improve teaching in their college and to research distance learning in the emergency situation caused by COVID-19. The survey was carried out in a digital format (Google Forms) and consisted of four closed-ended (multiple choice) questions about issues 
related to self-regulated learning (SRL). The questions were taken from a questionnaire on readiness for distance learning (Bernard et al., 2004), which contained four closed-ended questions in the form of a 7-point Likert scale ranging from "strongly agree" to "strongly disagree" (reliability factor: 0.87), and three open-ended questions on the nature of the participant's relationship with the teacher.

The closed-ended questions:

1. When it comes to learning and studying, I am a self-directed/regulated person.

2. In my studies, I am self-disciplined and find it easy to set aside reading and homework time.

3. I am able to manage my study time effectively and easily complete assignments on time.

4. In my studies, I set goals and have a high degree of initiative.

The open-ended questions:

5. Describe your relationship with your instructors this semester.

6. Give several examples of interactions with your instructors.

7. Were these interactions helpful? How?

The questions about teacher-student interaction were selected based on studies that indicate the importance of this type of interaction for learning in general (Ahmad et al., 2017; Maulana et al., 2014), for distance learning in particular (Manusov, 2016; Wright et al., 2015), and during the emergency situation created by the COVID-19 pandemic, based on students' reports (Khalil et al., 2020; Nambiar, 2020). This study analyzed the 591 answers received to the open-ended questions about the quality of interaction with the teacher. In the first stage of analysis, the students' answers to the open-ended questions were divided according to the median of their responses to the closed-ended questions in the survey on self-regulated learning. The median score for these questions was 5.25. Students who received a score above the median were regarded as having a high level of self-regulation, and students who received a score below the median were regarded as having a low level of self-regulation. The reason the students' responses to the open-ended questions were categorized based on their selfregulation is that studies have shown variance in reports about the nature and quality of the different types of teacher-student interactions based on the characteristics of the learners (Su et al., 2005). Our hypothesis was that self-regulation may be one of the contributors to this variance.

In the second stage, a qualitative analysis of the students' answers to the open-ended questions (Saris \& Gallhofer, 2014) was carried out. The statements were read by three researchers, who performed a textual-interpretative content analysis using a qualitative configuration (Krippendorff, 2013; Miles \& Huberman, 2000; Neuendorf, 2017) based on the grounded theory strategy (Glaser \& Strauss, 1967). This methodology was selected because the content was language-based, resembling an open dialog that involves two processes - forming an affiliation between the interviewer and the interviewees and producing information. This type of analysis offers the opportunity to understand the perspective of each participant about interactions with teachers, because of the detailed, extensive answers provided. On the other hand, the large number of answers makes it possible to draw a general picture of the different types of interactions and to compare the students' statements. This method involved sorting phenomena and breaking down a continuum of data to expose the themes in the participants' answers to the open-ended questions and the significance of the data retrieved. The features were then categorized into groups with common denominators. The categorization process consisted of two stages: dividing the findings based on the distinct types of interactions and the characteristics of each type and associating them with categories that connect the texts to one another (Charmaz, 2006; A. Strauss \& Corbin, 1990). This analysis showed that the answers to the open-ended questions contained substantial, profound textual information about the nature of the interactions that the students experience with their teachers. The large number of responses and their extensive detail, facilitated a more in-depth analysis of the nature and category of each interaction described, based on the model presented in Kang (2009) and Kang \& Lm (2013). 
The statements were then coded, based on the assumption that reports on a human experience contain patterns and repetitions that can be revealed in open-ended survey questions and careful, structured, systematic searches for contexts and structures. The first stage was open coding, in which the statements were divided according to subjects, i.e., initial conceptualization. The next stage was axial coding, in which the coded concepts were divided into meta-categories and sub-categories. The final stage of this process was selective coding, in which we continued examining the categories found and removed those that were nonessential for comparing our findings with the categories identified by Kang (2009) and Kang and Im (2013) for teacher-student interactions during routine times. During the selective coding stage, the relationships between the different concepts and categories were examined and those that corresponded with the "main themes" (Shkedi, 2003) were selected and used by the researchers to formulate their theories. (Table 2 demonstrates how the statements were analyzed and categorized.)

\section{FINDINGS}

\section{THE NEED FOR INTERACTION}

The students' answers indicated their desire and need for interaction with their teachers during distance learning. This was indicated by all students, whether they answered that good interaction was created with the teachers or maintained that "there is no interaction at all," that "the interaction is fairly dry," etc. According to the students, the distance and the absence of face-to-face meetings made it more difficult to create optimal interactions. One student described the challenge:

It's very difficult to interact with teachers during distance learning. It's difficult to see facial expressions, impossible to ask questions or chat between lessons.... This week, I wanted to tell the teacher that her lessons make me happy, and that whenever I forget why I chose this degree, her lessons remind me ... but writing it in an email seemed strange, saying it in the corridor would be much more legitimate.

The desire for interaction is very strong. Some participants even described reading out names to check attendance as a form of interaction with the teacher: "There isn't really any interaction, there are teachers who don't even take attendance."

One student described a situation that highlights this need, without saying so explicitly:

A teacher I sent an email to with questions for elaboration ... answered me but added that I could also look. for the answers on the internet on my own... I know how to search the internet, I asked bim because I wanted a different answer.

Another student expressed a need for closer interaction: "A teacher told us that we could send him Whats Apps and messages but when we send him a Whats App he answers: Send me an email and then I'll respond." Although it is easy to communicate by email, communication by WhatsApp is considered closer and faster, and it seems that the student was seeking closer interaction. In this case, the student expected interaction and also took initiative. However, some students said that they did not know how to initiate interaction and needed guidance: "I don't really know how to approach them ... in the actual lesson it's excellent. Outside the lesson, I don't really know what to do if I have questions or comments."

According to the students, in some cases the absence of adequate communication with the teacher can cause them to drop out of the course. As one of the students said explicitly: "T had to drop out of the course because the teacher didn't interact with me."

\section{SELF-REGULATION IN LEARNING AND INTERACTION WITH THE TEACHER}

When categorizing the participants according to their level of self-regulated learning, we found that most students who reported having no interaction with the teacher or described their interaction as poor or inadequate were those who also reported a low level of self-regulation in distance learning. Some of these students placed responsibility for interaction entirely on the teacher. For example: 
Teacher-Student Interaction in Distance Learning in Emergency Situations

"They don't help as they did before COVID and aren't considerate." They advise the teachers to "ask more questions and encourage active student participation, as this would strengthen the interactions between everyone." Some students with high levels of self-regulation reported a lack of interaction (though relatively few) but took more responsibility for this situation. For example: "I don't initiate discussions with the teachers and therefore we bave no interaction."

\section{TYPES OF INTERACTION}

In order to characterize the types of interaction encountered by students during emergency distance learning, their answers were divided into the categories defined by Kang (2009) and Kang and Im (2013; see Table 2).

Table 2: Examples of statements and their categories

\begin{tabular}{|c|c|c|}
\hline $\begin{array}{c}\text { Type of } \\
\text { interaction }\end{array}$ & Explanation of the category & $\begin{array}{l}\text { Examples of statements from an- } \\
\text { swers to the open-ended question }\end{array}$ \\
\hline $\begin{array}{l}\text { The need for } \\
\text { interaction } \\
\text { (general) }\end{array}$ & & $\begin{array}{l}\text { "I had to drop out of the course be- } \\
\text { cause I was ignored by the teacher." }\end{array}$ \\
\hline $\begin{array}{l}\text { Instructional com- } \\
\text { munication (Q\&A) }\end{array}$ & $\begin{array}{l}\text { Pedagogical changes to interactions re- } \\
\text { lated to communication between } \\
\text { learners and instructors about topics } \\
\text { directly related to the learning mate- } \\
\text { rial. }\end{array}$ & $\begin{array}{l}\text { "We can ask any question we have (in } \\
\text { the WhatsApp group) ... and he an- } \\
\text { swers gladly and patiently. It's very } \\
\text { nice..." }\end{array}$ \\
\hline $\begin{array}{l}\text { Guidance and } \\
\text { facilitation }\end{array}$ & $\begin{array}{l}\text { Interaction that is not directly related } \\
\text { to the learning material, but makes } \\
\text { learners perceive social changes } \\
\text { caused by the guidance and facilitation } \\
\text { provided by the instructor. }\end{array}$ & $\begin{array}{l}\text { "There was an assignment in the } \\
\text { course that I found difficult and I } \\
\text { spoke to the teacher. In response, she } \\
\text { extended the deadline for all of us," }\end{array}$ \\
\hline Social intimacy & $\begin{array}{l}\text { Interaction that is not directly related } \\
\text { to learning, but makes learners per- } \\
\text { ceive social change through introduc- } \\
\text { tions, greetings, and exchange of per- } \\
\text { sonal information. }\end{array}$ & $\begin{array}{l}\text { "We start the lesson with a short in- } \\
\text { troduction." } \\
\text { "Wow... what a nice shirt' and so on." }\end{array}$ \\
\hline Instructional support & $\begin{array}{l}\text { Interaction that makes learners per- } \\
\text { ceive the pedagogical change from in- } \\
\text { teraction that comes from instruc- } \\
\text { tional management by the instructor, } \\
\text { including supportive learning materials } \\
\text { and feedback directly related to the } \\
\text { learning materials. }\end{array}$ & $\begin{array}{l}\text { "He always responds and makes an } \\
\text { effort ... also for assignments that I } \\
\text { send to him. There is really a sense } \\
\text { of dialogue and in-depth learning } \\
\text { from my point of view." }\end{array}$ \\
\hline $\begin{array}{l}\text { Instructor's } \\
\text { presence }\end{array}$ & $\begin{array}{l}\text { Interaction that makes learners per- } \\
\text { ceive the presence of the instructor in } \\
\text { online learning environments. }\end{array}$ & $\begin{array}{l}\text { "I feel that they see me, and I am } \\
\text { more than a square in Zoom" }\end{array}$ \\
\hline
\end{tabular}

\section{Instructional communication}

This study found that the most common form of interaction reported by students was instructional communication based on questions and answers about teaching and the learning material. This was the preferred interaction by students with high levels and low levels of self-regulation. For example, 
one student said: "There was a course where I couldn't understand very well how to do something, I sent bim an email and within balf an hour, he answered in detail until I understood."

The students noted that most of the teachers were very accessible and answered their questions quickly and effectively. Some answered questions by email, others opened designated WhatsApp groups for questions and answers, and some opened forums for this purpose. "We can ask any question we have (in the Whats App group) ... and he answers gladly and patiently. It's very nice..."

It seems that from the students' perspective, interaction based on questions and answers is also preferred by teachers: "Many of the teachers really emphasize that they are happy to receive questions and explain if something is unclear, I felt comfortable sending emails with questions to several teachers and they answered quickly and patiently, and I really appreciate that." Another student said that "The teachers beg us to talk with them."

There were students who regarded remote communication as better than face-to-face communication, specifically because of the ability to communicate remotely via questions and answers: "I write to them much more in emails and they are very responsive, which I might be embarrassed to do face to face in class." Another student said: "Due to distance learning, someone quiet like me who usually doesn't ask questions in class can actually ask."

\section{Guidance and facilitating learning}

Many students reported interaction based on guidance and teachers' consideration for their needs during learning. This interaction is not directly related to the learning material, but rather to guiding and facilitating learning activities. They reported that during the ERT forced upon them by the pandemic, the teachers "are aware of our needs," and "try to see how they can belp and meet us halfway, which is not something that can be taken for granted." The students described how the teachers came to their assistance. For example, 'The teachers also listen to the students' complaints about their heavy workload, and ease their demands to various extents". They gave different examples of interactions in which the teacher was considerate and helped support their learning:

"There was an assignment in the course that I found difficult and I spoke to the teacher. In response, she extended the deadline for all of us,"

"The fact that I gave birth at the beginning of the semester and the teachers were considerate of this,"

"Ms. ... met me halfway because I missed the deadline for submitting an assignment due to a problem that I had with my home internet connection for a few days. She extended the deadline for the assignment for me personally, and I greatly respect her for this."

Several examples of students' unmet expectations for interaction that involved facilitation and consideration appear in the following statements:

"One day I was in the car during a lesson.... After the lesson, the teacher sent me an email saying that he expects me not to attend his lectures while driving. I would have expected slightly more tolerance and acceptance considering that it was definitely a one-time incident."

'I was sick for a while and it took time until I recovered. ... I spoke to two teachers privately and explained my situation to them. One really understood, was very patient and sensitive, and extended the deadline for submitting the assignment. But the other teacher refused. His answer was very cold and unpleasant and made me feel a certain lack of consideration and lack of willingness to listen. It really upset me and disappointed me."

Students expected interaction that could facilitate their learning activities during the challenging period they were undergoing. Overall, they experienced the accepting and considerate interaction they expected. 


\section{Social intimacy}

The kind of interaction mentioned by the fewest students was personal interaction that was not connected specifically to learning, such as warm greetings or sharing personal information. Those who reported such interactions said that the teacher asked how they were doing and took interest in how they were coping with the situation. The students said that this interaction gave them "a good and pleasant feeling" and "warms the heart."

One student described a class in which it was important to the teacher to create personal interactions with the students: "He begins the lesson with briefly getting to know one another and speaks a bit about everyday events." There were students who maintained that distance learning actually contributed to personal interactions:

I think that the distance actually created this closeness because in class, there is the status of teacher and student; the teacher sits at a different table at a distance from the students, whereas in Zoom, when everyone is in front of a computer everyone looks the same and the teacher also feels and looks like everyone else so I believe it even created greater closeness.

One student noted the importance of personal interaction: "There are teachers who also see you and notice you - "Wow... what a nice shirt' and so on." Another student said: "When the teacher addresses one of the students who answered a question in class, be mentions the student's name. This shows the importance of interacting personally with each of the students."

\section{Instructional support}

The students who reported experiencing interaction in the form of instructional support in which the teacher helped and supported the student with the academic material said that the teachers were willing to help whenever asked: "They make excellent comments that help me improve all the time."

They said that the teachers provided detailed, educational feedback about the assignments handed in, in order to constantly improve the learning process: "He always responds and makes an effort ... also for assignments that I send to him. There is really a sense of dialogue and in-depth learning from my point of view." They said that this feedback is extremely important to them, both in order to understand the material and to encourage and motivate them to improve their learning:

There is encouragement on their part and it's empowering. For example, I was surprised by the encouragement I received from a teacher who sent me an email saying that she enjoyed reading my work. This gave me drive to continue and succeed.

In addition to providing feedback, students described how their teachers initiated interaction by consistently sending material: "They offer help for students who have a hard time and don't understand." and "They send material on Whats App in advance."

\section{Instructor's presence.}

Many students reported interactions that were connected to their perception of how present the teacher was in the learning process. They reported that the teachers noticed them and their participation in class. A student said: "I feel that they see me, and I am more than a square in Zoom." In addition, they described the teachers as taking interest and adjusting their teaching to the students' needs: "The teacher asked us privately if it's alright if he speeds up the pace." "There are teachers who really want to enhance the learning process; to adapt it to our needs." The students greatly appreciated the teachers who invested in this interaction: "Those for whom the students' development is really and genuinely important, and even if you receive a low grade, you can improve it because in the end, what is important is the student's progress." 


\section{DisCUSSION}

The COVID-19 pandemic forced the education system in general and the academia in particular to change their methods of teaching and learning within a short time (Altbach \& de Wit, 2020; Lipsitch et al., 2020). Interaction between teachers and students changed suddenly from interaction that mostly took place face-to-face to remote interaction (Hodges \& Fowler, 2020). This study was conducted among BA students at a teachers' training college after one semester of emergency remote learning. It examined which types of interaction that were found in previous studies in routine situations (Kang, 2009; Kang \& Im, 2013) were also reported in times of emergency; which types of interaction were most common, and whether there was a difference between how different students related to these interactions.

\section{THE NEED FOR INTERACTION}

This study's findings reflect the students' desire and need for interaction with their teachers during emergency distance learning, which coincides with previous research about distance learning in routine situations (e.g., Burnett et al., 2007; Sher, 2009; and Wright et al., 2015), and during the COVID19 pandemic (e.g., Adnan \& Anwar, 2020; Mohmmed et al., 2020; Nambiar, 2020). Students described this interaction as essential for learning, coping with distance learning, and succeeding in their studies. Previous studies about the connection between teacher-student interaction and success in distance learning noted the importance of this interaction for optimal learning (Murphy \& Rodríguez-Manzanares, 2012; Wright et al., 2015) and maintained that a lack of sufficient interaction may cause students to drop out of the course (Y. Lee \& Choi, 2011; Yerby, 2017), as one of the students in this study stated explicitly.

In distance learning, interpersonal interaction is maintained by utilizing the range of available interactive tools and technology such as email, WhatsApp, and cellphones. Hodges and Fowler (2020) maintained that interactions based on these technologies are deficient because of the absence of physical gestures, eye contact, and a classroom and campus atmosphere. This is consistent with the difficulty in communication reported by the students and their desire for closer communication, as indicated, for example, by a student who said he knew how to search for answers on the internet but preferred an answer from the teacher.

Students perceive WhatsApp to be a better tool for communication than email. The study found that students complained when a teacher asked them to send emails, rather than posting on social media, which coincides with findings from other studies conducted during the COVID-19 pandemic (Mishra et al., 2020). It seems that from the teachers' perspective, WhatsApp blurs the boundaries between academic space and personal space, as was found by Susilo (2014). For students, on the other hand, the mobile phone is more accessible than email and they expect quicker, more accessible responses. Mahyoob (2020) noted the efficiency of interacting via WhatsApp because of its availability. WhatsApp also creates interactions between people within a personal circle, which may be why it represents closer interaction from the students' perspective (Rosenberg et al., 2017).

Learners are familiar with the personal, verbal, and direct interaction that occurs in face-to-face learning settings and in the corridors before and after actual learning. It seems obvious to them and integral to their learning experience. However, when it must be adapted for remote interaction tools, it becomes more difficult. The students complained about the difficulty in contacting their teachers, asking questions, talking to them between classes, and seeing facial expressions when learning online. They said that there are things that can be said aloud, but not put in writing, and these opportunities were lacking during distance learning. Khalil et al. (2020) found that the lack of non-verbal communication between teachers and students was described as one of the most significant challenges during distance learning. 
Teacher-Student Interaction in Distance Learning in Emergency Situations

This may demonstrate what Bozkurt and Sharma (2020), Brady and Pradhan (2020), and Mohmmed et al. (2020) wrote about the rapid transition from traditional learning, which the teachers and the learners were used to, to emergency remote learning and the challenges posed by the fact that there was not enough time to adjust and adapt to it.

\section{INTERACTION AND THE LEVEL OF SELF-REGULATED LEARNING}

Studies have shown that self-regulation affects students' ability to develop the skills needed for distance learning (e.g., Greene et al., 2018; Kiliç-Çakmak, 2010). When distinguishing between students based on their reports on self-regulation, those who reported higher levels of self-regulation also reported more interaction with their teachers and took more responsibility for this interaction regardless of its extent. Students who reported lower levels of self-regulation also reported insufficient interaction with their teachers, and many expected the teacher to take full responsibility for initiating interaction. For example, they expected the teachers to ask them more questions and encourage them throughout the learning process.

It is possible that, from the perspective of all students, teachers are responsible for all aspects of teaching, including interaction with the students. However, students will high self-regulatory capabilities are more skilled at managing their learning and recruit the motivation and strategies needed to facilitate it, including optimal management of their interaction with their teachers.

Su et al (2005) found that students differ in their perceptions of the importance of online interaction and their expectations of their instructors to initiate and manage interaction. Some students seek additional interaction and some prefer only minimal interaction. The researchers hypothesized that these differences may be related to personality traits or learning styles. The findings from this study regarding the connection between students' self-regulation and their expectations may explain the findings in Su et al., as the differences may be related to students' self-regulation.

\section{TYPES OF INTERACTION BETWEEN TEACHERS AND STUDENTS}

\section{Instructional communication}

The type of interaction that is most common, according to the students' reports, is instructional communication, which focuses on questions and answers about topics included in the course. This is apparently because of the teacher and students' mutual understanding that learning the course material is their main form of interaction, and therefore the simplest and easiest way to communicate is by means of questions and answers. This enables the teacher to focus on the students' questions and difficulties, and to address their specific needs.

This preference for instructional communication is consistent with studies on distance learning that found that quick, specific answers to learners' questions increase their confidence, motivation (Gelbart, 2000) and sense of efficacy (Harlen, 2006). Kang and Im (2013) noted that this type of interaction is the main predictor of students' achievements and satisfaction in distance learning.

Some of students reported that distance learning actually enhanced their ability to communicate with the teachers and contact them directly and optimally, sometimes even more than in regular learning. These students said that they felt more comfortable sending emails or WhatsApp messages to their teachers than under regular circumstance.

Some reported that the ability to "hide" behind the technological tools makes it easier for shyer students to ask questions. Furthermore, the fact that distance learning sometimes traverses the limits of time (for example in asynchronous lessons) may help learners feel more comfortable asking the teacher questions about the material at any time. Perhaps the teachers also feel more committed to being available and to answering the students' questions in distance learning. It is possible that the sense of emergency when learning during the COVID-19 pandemic increased the teachers' 
commitment to being available and enhanced the students' sense that the limits are more flexible in this situation, as they expected their teachers to be more accessible during the emergency situation (Adnan \& Anwar, 2020).

It would be interesting to explore the characteristics of the students who prefer distance learning, as this may be a preferrable option for shyer students.

\section{Guidance and facilitating learning}

This type of interaction did not relate directly to the learning material, but rather to the fact that the teacher had consideration for the students and their individual needs, which facilitated learning. Many students saw the teacher's willingness to meet them halfway, facilitate, and have consideration for them as a form of interaction, and when this happened in a way that seemed satisfactory, they reported having "good interaction" with the teacher. For example, they described a good relationship as one in which the instructors listen to the students' complaints, allow them to "let off steam," and more.

Considering the reports given by the students in this category, it seems that this type of interaction, though related only indirectly to the content of the course, can contribute significantly to building relationships between teachers and students and influence students' satisfaction with the course (Murphy \& Rodríguez-Manzanares, 2012; Reupert et al., 2009). However, according to several reports, this category was only the second most prevalent one, after direct interaction involving questions and answers about the learning material. It seems that students also realized that the learning setting was secondary to questions that focus on the learning itself and on the course material. Nevertheless, a large number of students expected more guidance and consideration, possibly due to the difficult emergency situation that challenged their learning routines during this time.

\section{Social intimacy}

This type of interaction between the teacher and the student was mentioned least in the students' reports. However, students who did report it testified to how necessary and important it was, especially in view of the physical distance and the isolation that social distancing forced upon them. They reported that even teachers who noticed a change in their appearance or called them by name offered a sense of social intimacy. Mishra et al. (2020) showed that some instructors felt obligated to take interest in their students and talk to them at the beginning or end of their Zoom lessons about topics unrelated to learning or to their course.

Previous studies on distance learning in routine situations indicated the importance of this type of interaction and found that personal interaction and social intimacy are related to students' satisfaction and achievements (Garrison, 2011; Jung et al., 2002), but, Kang and Im (2013) found that personal communication and social intimacy may inhibit students' perceived learning achievements and satisfaction, which may explain the infrequency of this type of interaction in the students' reports. The fact that in an emergency situation most students are focused on "surviving" their studies and are less emotionally available for personal interaction may also explain this finding. They may perceive this type of interaction as taking place at the expense of interaction that facilitates learning. This notion is supported by several studies, such as Hagenauer \&Volet (2014) or Sibii (2010), who claimed the interpersonal relationships between students and teachers in higher education must be balanced correctly and not exceed certain boundaries, and that they should not be "friends". The finding about the appropriate boundaries of the teacher-student relationship in higher education, and specifically in

distance learning, deserves additional research, in view of the contradictions with studies that showed its importance and contribution, and of different perceptions of the role of "instructor" and "learner" in the academia. 


\section{Instructional support}

There were relatively few reports about interaction for purposes of instructional support, such as feedback on assignments, corrections, explanations, and summaries, and about teachers who encouraged students who needed help to contact them. However, when this type of interaction was reported, the students directly associated it with the quality of learning and ability to learn in a more orderly manner despite the situation. As in previous studies on distance learning and in a study from the COVID-19 period (Rapanta et al., 2020), ongoing evaluation of the students' performance, immediate feedback, and individual assistance were found to contribute to students' success (Swan, 2003).

\section{Instructor's presence}

Another type of interaction reported by the students was the instructor's presence in distance learning. The students reported their appreciation for teachers who took an interest in their learning, clearly wanted them to succeed, and "saw" them in class. As a student said: "I feel that they see me, and I am more than a square in Zoom." Lehman and Conceição (2010) found that instructor's presence encouraged student involvement in learning, and Kang and Im (2013) and Shea et al., (2006) found that this factor could predict students' satisfaction with distance learning. This study and Rapanta et al. (2020) noted the importance of this interaction for students during distance learning in emergency situations as well.

They reported its contribution to their sense of satisfaction and noted that this type of interaction was generally less verbal and more textual - based mostly on emails, WhatsApp messages, and Learning Management Systems (LMS) such as Moodle, and Google Classroom. The teachers apparently found these platforms most convenient for taking specific interest in their students' learning.

\section{CONCLUSION}

The findings of this study on distance learning during an emergency situation in which all learning took place remotely indicated the importance of different types of interaction between teachers and student during such times. The findings show that any type of interaction that supports teaching can improve the learning process itself and help students complete their courses to their satisfaction. The students' answers indicate that they prefer certain types of interaction over others. Therefore, teachers should internalize the importance of interacting with their students and not regard creating various types of interaction as a "waste" of precious class time. The purpose of teaching is to facilitate students' learning, and therefore teachers must find the correct balance between directly teaching the material and providing a support network based on interactions that can improve and augment learning, especially during times of crisis and emergency.

The theoretical contribution of this study is related to the ability to analyze students' perceptions of their interactions with their instructors during distance learning in emergency situations, in order to pinpoint the specific types of interactions students expect under such circumstances. It has a practical contribution as well, as it increases academic instructors' understanding of the importance of different types of interactions with their students and their ability to develop these interactions (including those that are not directly related to the course's subject matter) over diverse channels.

Therefore, it is also recommended that colleges and universities issue appropriate guidelines on the importance of developing interaction between the teachers and students, and encourage the development of diverse types of interaction, even at the expense of official class time (while maintaining an optimal balance), given the contribution of this interaction towards high-quality learning.

An additional recommendation is to develop workshops for teachers in which they can experiment with creating different types of interaction during and between lessons, particularly in distance learning. 


\section{LIMITATIONS AND RECOMMENDATIONS FOR FUTURE RESEARCH}

The participants in this study were students in a teachers' training college, and therefore have specific characteristics as pre-service teachers that distinguish them from other students. It is possible that the findings would have been different if the research had been carried out among students in other colleges and universities and in different departments. The fact that the research took place in one college may also affect its generality. In this study, the participants were undergraduate students studying education in different departments in the college, and the differences in teacher-student interactions between the different degrees and departments were not explored. It would be worth examining these differences in future research. It is also recommended to elaborate upon how students' characteristics and self-regulation influence the type of relationship they seek with their instructors. Indications of this connection were found in this study, but further research is required.

It would also be interesting to explore the teachers' perceptions of the teacher-student interaction and compare their perspectives with those of the students.

\section{ACKNOWLEDGEMENT}

This article was supported by Herzog Academic College.

\section{REFERENCES}

Adnan, M., \& Anwar, K. (2020). Online Learning amid the COVID-19 Pandemic: Students' Perspectives. Journal of Pedagogical Sociology and Psychology, 2(1), 45-51. https://doi.org/10.33902/JPSP.2020261309

Ahmad, C. N. C., Shaharim, S. A., \& Abdullah, M. F. N. L. (2017). Teacher-student interactions, learning commitment, learning environment and their relationship with student learning comfort. Journal of Turkish Science Education, 14(1), 57-72.

Allen, I. E., \& Seaman, J. (2013). Changing course: Ten years of tracking online education in the United States. Babson College/Quahog Research Group.

Almuraqab, N. A. S. (2020). Shall universities at the UAE continue distance learning after the COVID-19 pandemic? Revealing students' perspective. International Journal of Advanced Research in Engineering and Technology (IJARET), 11(5).

Altbach, P. G., \& de Wit, H. (2020). Are we at a transformative moment for online learning? University World News, 2 .

Artino, A. R. (2007). Self-regulated learning in online education. International Journal of Instructional Technology Distance Learning, 4(6), 3-18. http://itdl.org/Journal/Jun 07/article01.htm

Bernard, R. M., Brauer, A., Abrami, P. C., \& Surkes, M. (2004). The development of a questionnaire for predicting online learning achievement. Distance Education, 25(1), 31-47. https://doi.org/10.1080/0158791042000212440

Bozkurt, A., \& Sharma, R. C. (2020). Emergency remote teaching in a time of global crisis due to coronavirus pandemic. Asian Journal of Distance Education, 15(1), i-vi.

Brady, A. K., \& Pradhan, D. (2020). Learning without borders: Asynchronous and distance learning in the age of COVID-19 and beyond. ATS Scholar, 1(3), 233-242. https://doi.org/10.34197/ats-scholar.2020$\underline{0046 \mathrm{PS}}$

Brenton, S. (2014). Effective online teaching and learning. In H. Fry, S. Ketteridge, \& S. Marshall (Eds.), A handbook for teaching and learning in higher education (pp. 161-173). Routledge.

Burnett, K., Bonnici, L.J., Miksa, S.D., \& Kim, J. (2007). Frequency, intensity and topicality in online learning: An exploration of the interaction dimensions that contribute to student satisfaction in online learning. Journal of Education for Library and Information Science, 48(1), 21-35. 
Teacher-Student Interaction in Distance Learning in Emergency Situations

Butler, D. L., \& Cartier, S.C. (2005, April). Multiple complementary methods for understanding self-regulated learning as situated in context. Accepted for presentation at the annual meetings of the American Educational Research Association, Montreal, QC.

Calvo, R. A., Markauskaite, L., \& Trigwell, K. (2010). Factors affecting students' experiences and satisfaction about teaching quality in engineering. Australasian Journal of Engineering Education, 16(2), 139-148. https://doi.org/10.1080/22054952.2010.11464049

Carter, R. A., Jr., Rice, M., Yang, S., \& Jackson, H. A. (2020). Self-regulated learning in online learning environments: Strategies for remote learning. Information and Learning Sciences. https://www.emerald.com/insight/content/doi/10.1108/ILS-04-2020-0114/full/html

Charmaz, K. (2006). Constructing grounded theory: A practical guide through qualitative analysis. Sage.

Cho, M. H., \& Shen, D. (2013). Self-regulation in online learning. Distance Education, 34(3) 290-301. https://doi.org/10.1080/01587919.2013.835770

Cole, A., Anderson, C., Bunton, T., Cherney, M., Fisher, V. C., Featherston, M., Motel, L., Nicolini, K., Peck, B., \& Allen, M. (2017). Student predisposition to instructor feedback and perceptions of teaching presence predict motivation toward online courses. Online Learning Journal, 21(4), 245-262. https://doi.org/10.24059/olj.v21i4.966

Collison, G., Elbaum, B., Havind, S., \& Tinker, R. (2000). Facilitating online learning: Effective strategies for moderators. Atwood.

Conard, R. M., \& Donaldson, J. A. (2012). Continuing to engage the online learner. Jossey-Bass. A Wiley Imprint.

Crawford, J., Butler-Henderson, K., Rudolph, J., Malkawi, B., Glowatz, M., Burton, R., Magni, P., \& Lam, S. (2020). COVID-19: 20 countries' higher education intra-period digital pedagogy responses. Journal of Applied Learning \& Teaching, 3(1), 1-20. https://doi: 10.37074/jalt.2020.3.1.7

Deci, E. L., \& Ryan, R. M. (2012). Motivation, personality, and development within embedded social contexts: An overview of self-determination theory. In R. M. Ryan (Ed.), The Oxford Handbook of Human Motivation (pp. 85-107). Oxford University Press.

Dobransky, N. D., \& Frymier, A. B. (2004). Developing teacher-student relationships through out of class communication. Communication Quarterly, 52, 211-223. https://doi.org/10.1080/01463370409370193

Donitsa-Schmidt, S., \& Topaz, B. (2018). Massive open online courses as a knowledge base for teachers. Journal of Education for Teaching, 44(5), 608-620. https://doi.org/10.1080/02607476.2018.1516350

Eccles, J. S. (2004). Schools, academic motivation, and stage-environment fit. In R. M. Lerner \& L. Steinberg (Eds.), Handbook of Adolescent Psychology (pp. 125-153). John Wiley \& Sons Inc.

Fredericksen, E., Pickett, A., Pelz, W., Swan, K., \& Shea, P. (2000). Student satisfaction and perceived learning with on-line courses: Principles and examples from the SUNY learning network. Online Learning, 4(2). https://doi.org/10.24059/olj.v4i2.1899.

Frymier, A. B. (2007, November). Teachers' and students' goals in the teaching-learning process. In Annual Meeting of the National Communication Association, Chicago, IL.

Garrison, D. R. (2011). E-learning in the 21st century: A framework for research and practice. Taylor \& Francis.

Gelbart, R. (2000). Improving collaboration in distance learning courses [Unpublished doctoral dissertation, Nova Southeastern University].

Glaser, B. G. and Strauss, A. L. (1967). The discovery of grounded theory: Strategies for qualitative research. Aldine Transaction.

Greene, J. A., Copeland, D. Z., Deekens, V. M., \& Seung, B. Y. (2018). Beyond knowledge: Examining digital literacy's role in the acquisition of understanding in science. Computers \& Education, 117, 141-159. https://doi.org/10.1016/j.compedu.2017.10.003

Hagenauer, G., \& Volet, S. E. (2014). Teacher-student relationship at university: An important yet under-researched field. Oxford Review of Education, 40(3), 370-388. https://doi.org/10.1080/03054985.2014.921613 
Hara, N., \& Kling, R. (2001). Student distress in web-based distance education. Educause Quarterly, 24(3), 68-69.

Harlen, W. (2006). The role of assessment in developing motivation for learning. In J. R. Gardner (Ed.), Assessment and learning (pp. 61-80). Sage

Heo, J., \& Han, S. (2018). Effects of motivation, academic stress and age in predicting self-directed learning readiness (SDLR): Focused on online college students. Education and Information Technologies, 23(1), 61-71. https://doi.org/10.1007/s10639-017-9585-2

Hodges, C., \& Fowler, D. (2020). COVID-19 crisis and faculty members in higher education: From emergency remote teaching to better teaching through reflection. International Journal of Multidisciplinary Perspectives in Higher Education, 5(1), 118-122. https://doi.org/10.32674/jimphe.v5i1.2507

Hodges, C., Moore, S., Lockee, B., Trust, T., \& Bond, A. (2020). The difference between emergency remote teaching and online learning. Educause Review, 27.

Holmes, D. L., Rupert, P. A., Ross, S. A., \& Shapera, W. E. (1999). Student perceptions of dual relationships between faculty and students. Ethics \& Behavior, 9(2), 79-106. https://doi.org/10.1207/s15327019eb0902 1

Jansen, R. S., Van Leeuwen, A., Janssen, J., Kester, L., \& Kalz, M. (2017). Validation of the self-regulated online learning questionnaire. Journal of Computing in Higher Education, 29(1), 6-27. https://doi.org/10.1007/s12528-016-9125-x

Javid, S. A., Zahed-Babelan, A., \& Namvar, Y. (2013). A study on the state of teacher-student verbal interactions during teaching process and its relationship with academic achievement of middle school students in Ardabil. International Research Journal of Applied and Basic Sciences, 4(7), 1909-1913.

Jung, I., Choi, S., Lim, C., \& Leem, J. (2002). Effects of different types of interaction on learning achievement, satisfaction and participation in web-based instruction. Innovations in Education and Teaching International, 39(2), 153-162. https://doi.org/10.1080/14703290252934603

Kang, M. (2009). Development of learners' perceived interaction model and scale between learner and instructor in e-learning environments [Unpublished doctoral dissertation], Korea University.

Kang, M., \& Im, T. (2013). Factors of learner-instructor interaction which predict perceived learning outcomes in online learning environment. Journal of Computer Assisted Learning, 29, 292-301. https://doi.org/10.1111/jcal.12005

Khalil, R., Mansour, A. E., Fadda, W. A., Almisnid, K., Aldamegh, M., Al-Nafeesah, A., Alkhalifah, A., \& AlWutayd, O. (2020). The sudden transition to synchronized online learning during the COVID-19 pandemic in Saudi Arabia: A qualitative study exploring medical students' perspectives. BMC Medical Education, 20, Article 285. https://doi.org/10.1186/s12909-020-02208-z

Kiliç-Çakmak, E. (2010). Learning strategies and motivational factors predicting information literacy self-efficacy of e-learners. Australasian Journal of Educational Technology, 26(2). https://doi.org/10.14742/ajet.1090

Kim, K. J., Liu, S., \& Bonk, C. J. (2005). Online MBA students' perceptions of online learning: Benefits, challenges, and suggestions. Internet and Higher Education, 8, 335-344. https://doi.org/10.1016/j.iheduc.2005.09.005

Kocdar, S., Karadeniz, A., Bozkurt, A., \& Buyuk, K. (2018). Measuring self-regulation in self-paced open and distance learning environments. International Review of Research in Open and Distributed Learning, 19(1). https://doi.org/10.1016/j.compedu.2017.10.003

Komarraju, M., Musulkin, S., \& Bhattacharya, G. (2010). Role of student-faculty interactions in developing college students' academic self-concept, motivation, and achievement. Journal of College Student Development, 51, 332-342. https://doi.org/10.1353/csd.0.0137

Krippendorff, K. (2013) Content analysis. An introduction to its methodology (3rd ed). Sage Publications.

Lazarevic, B., \& Bentz, D. (2021). Student perception of stress in online and face-to-face learning: the exploration of stress determinants. American Journal of Distance Education, 35(1), 2-15. https://doi.org/10.1080/08923647.2020.1748491 
Teacher-Student Interaction in Distance Learning in Emergency Situations

Leasure, A. R., Davis, L., \& Thievon, S. L. (2000). Comparison of student outcomes and preferences in a traditional vs. world wide web-based baccalaureate nursing research course. Journal of Nursing Education, 39(4). https://doi.org/10.3928/0148-4834-20000401-04

Lee, C. Y. (2015). Changes in self-efficacy and task value in online learning. Distance Education, 36(1), 59-79. https://doi.org/10.1080/01587919.2015.1019967

Lee, K., Choi, H., \& Cho, Y. H. (2019). Becoming a competent self: A developmental process of adult distance learning. The Internet and Higher Education, 41, 25-33. https://doi.org/10.1016/j.iheduc.2018.12.001

Lee, T. H., Shen, P. D., \& Tsai, C. W. (2008). Applying web-enabled problem-based learning and self-regulated learning to add value to computing education in Taiwan's vocational schools. Journal of Educational Technology \& Society, 11(3), 13-25.

Lee, Y., \& Choi, J. (2011). A review of online course dropout research: Implications for practice and future research. Educational Technology Research and Development, 59(5), 593-618. https://doi.org/10.1007/s11423-010$\underline{9177-y}$

Lehman, R. M., \& Conceição, S. C. (2010). Creating a sense of presence in online teaching: How to "be there" for distance learners (Vol. 18). John Wiley \& Sons.

Lipsitch, M., Swerdlow, D. L., \& Finelli, L. (2020). Defining the epidemiology of Covid-19 - Studies needed. New England Journal of Medicine, 382, 1194-1196. https://doi.org/10.1056/NEJMp2002125

Lundberg, C. A., \& Schreiner, L. A. (2004). Quality and frequency of faculty-student interaction as predictors of learning: An analysis by student race/ethnicity. Journal of College Student Development, 45(5), 549-565. https://doi.org/10.1353/csd.2004.0061

Mahyoob, M. (2020). Challenges of e-Learning during the COVID-19 pandemic experienced by EFL Learners. Arab World English Journal (AWEJ), 11(4). https://doi.org/10.24093/awej/vol11no4.23

Manusov, V. (2016). A history of research on nonverbal communication: Our divergent pasts and their contemporary legacies. In D. Matsumoto, H. C. Hwang, \& M. G. Frank (Eds.), APA handbook of nonverbal communication (pp. 3-15). American Psychological Association. https://doi.org/10.1037/14669-001

Maulana, R., Opdenakker, M. C., \& Bosker, R. (2014). Teacher-student interpersonal relationships do change and affect academic motivation: A multilevel growth curve modelling. British Journal of Educational Psychology, 84(3), 459-482. https://doi.org/10.1111/bjep.12031

Miles, M. B., \& Huberman, A. M. (2000). Analiza danych jakościonych [Qualitative data analysis]. Trans Humana.

Mishra, L., Gupta, T., \& Shree, A. (2020). Online teaching-learning in higher education during lockdown period of COVID-19 pandemic. International Journal of Educational Research Open, 1, 100012. https://doi.org/10.1016/j.ijedro.2020.100012

Mohmmed, A. O., Khidhir, B. A., Nazeer, A., \& Vijayan, V. J. (2020). Emergency remote teaching during coronavirus pandemic: The current trend and future directive at Middle East College Oman. Innovative Infrastructure Solutions, 5(3), 1-11. https://doi.org/10.1007/s41062-020-00326-7

Murphy, E., \& Rodríguez-Manzanares, M. A. (2012). Rapport in distance education. International Review of Research in Open and Distributed Learning, 13(1), 167-190. https://doi.org/10.19173/irrodl.v13i1.1057

Murphy, M., \& Valdéz, C. (2005). Ravaging resistance: A model for building rapport in a collaborative learning classroom. Radical Pedagogy, 7(1), 1-7.

Nambiar, D. (2020). The impact of online learning during COVID-19: students' and teachers' perspective. The International Journal of Indian Psychology, 8(2), 783-793.

Naujoks, N., Bedenlier, S., Gläser-Zikuda, M., Kammerl, R., Kopp, B., Ziegler, A., \& Händel, M. (2021). Selfregulated resource management in emergency remote higher education: Status quo and predictors. Frontiers in Psychology, 12, 1929. https://doi.org/10.3389/fpsyg.2021.672741

Neuendorf, K. A. (2017). The content analysis guidebook. Cleveland State University. 
Pajares, F., \& Schunk, D. H. (2002). Self and self-belief in psychology and education: A historical perspective. In J. Aronson (Ed.), Improving Academic Acbievement (pp. 3-21). Academic Press. https://doi.org/10.1016/B978-012064455-1/50004-X

Palloff, R. M., \& Pratt, K. (2001). Lessons from the cyberspace classroom. The realities of online teaching. Jossey-Bass.

Pianta, R. C., Hamre, B. K., \& Allen, J. P. (2012). Teacher-student relationships and engagement: Conceptualizing, measuring, and improving the capacity of classroom interactions. In S. L. Christenson, A. L. Reschly, \& C. Wylie (Eds.), Handbook of Research on Student Engagement (pp. 365-386). Springer.

Pintrich, P. R. (2000). The role of goal orientation in self-regulated learning. In. M. Boekaerts, P. R. Pintrich \& M. Zeidner (Eds.), Handbook of Self-Regulation (pp. 451-502). Academic Press.

Pintrich, P. R. (2004). A conceptual framework for assessing motivation and self-regulated learning in college students. Educational Psychology Review, 16(4), 385-407. https://doi.org/10.1007/s10648-004-0006-x

Puzziferro, M. (2008). Online technologies self-efficacy and self-regulated learning as predictors of final grade and satisfaction in college-level online courses. American Journal of Distance Education, 22(2), 72-89. https://doi.org/10.1080/08923640802039024

Rapanta, C., Botturi, L., Goodyear, P., Guàrdia, L., \& Koole, M. (2020). Online university teaching during and after the Covid-19 crisis: Refocusing teacher presence and learning activity. Postdigital Science and Education, 2(3), 923-945. https://doi.org/10.1007/s42438-020-00155-y

Reupert, A., Maybery, D., Patrick, K., \& Chittleborough, P. (2009). The importance of being human: Instructors' personal presence in distance programs. International Journal of Teacbing and Learning in Higber Education, 21(1), 47-56.

Rosenberg, H., Ophir, Y., \& Asterhan, C. (2017) Building adolescent resilience: Teacher-student social network communication in times of political violence. In B. B. Schwarz, H. Rosenberg, \& C. S. C. Asterhan (Eds.), Breaking down barriers in education? Teachers, students and social network sites (pp. 199-218) (In Hebrew). MOFET Books.

Rugutt, J., \& Chemosit, C. C. (2009). What motivates students to learn? Contribution of student-to-student relations, student-faculty interaction and critical thinking skills. Educational Research Quarterly, 32(3), 16.

Samruayruen, B., Enriquez, J., Natakuatoong, O., \& Samruayruen, K. (2013). Self-regulated learning: A key of a successful learner in online learning environments in Thailand. Journal of Educational Computing Research, 48(1), 45-69. https://doi.org/10.2190\%2FEC.48.1.c

Sander, P., Stevenson, K., King, M., \& Coates, D. (2000). University students' expectations of teaching. Studies in Higher Education, 25(3), 309-323. https://doi.org/10.1080/03075070050193433

Saris, W. E., \& Gallhofer, I. N. (2014). Design, evaluation, and analysis of questionnaires for survey research. John Wiley $\&$ Sons.

Schlesselman, L. S. (2020). Perspective from a teaching and learning center during emergency remote teaching. American Journal of Pharmaceutical Education, 84(8), ajpe8142. https://doi.org/10.5688/ajpe8142

Schraw, G. (2006). Knowledge: Structures and processes. In P. A. Alexander \& P. H. Winne (Eds.), Handbook of Educational Psychology (pp. 245-263). Erlbaum.

Shea, P., Li, C. S., \& Pickett, A. (2006). A study of teaching presence and student sense of learning community in fully online and web-enhanced college courses. The Internet and Higher Education, 9(3), 175-190. https://doi.org/10.1016/j.iheduc.2006.06.005

Sher, A. (2009). Assessing the relationship of student-instructor and student-student interaction to student learning and satisfaction in web-based online learning environment. Journal of Interactive Online Learning, $8(2)$.

Shkedi, A. (2003). Qualitative research theory and practice. Tel Aviv University. Ramot Press.

Sibii, R. (2010). Conceptualizing teacher immediacy through the 'companion' metaphor. Teaching in Higher Education, 15, 531-542. https://doi.org/10.1080/13562517.2010.491908 
Teacher-Student Interaction in Distance Learning in Emergency Situations

Stone, C., Freeman, E., Dyment, J. E., Muir, T., \& Milthorpe, N. (2019). Equal or equitable? The role of flexibility within online education. Australian and International Journal of Rural Education, 29(2), 26-40.

Strauss, A., \& Corbin, J. (1990). Basics of qualitative research. Sage Publications.

Strauss, L. C., \& Volkwein, J. F. (2004). Predictors of student commitment at two-year and four-year institutions. The Journal of Higher Education, 75(2), 203-227. https://doi.org/10.1080/00221546.2004.11778903

Su, B., Bonk, C. J., Magjuka, R. J., Liu, X., \& Lee, S. H. (2005). The importance of interaction in web-based education: A program-level case study of online MBA courses. Journal of Interactive Online Learning, 4(1), 1-19.

Susilo, A. (2014). Using Facebook and WhatsApp to leverage learner participation and transform pedagogy at the Open University of Indonesia. Journal Pendidikan Terbuka Dan Jarak Jauh, 15(2), 63-80. https://doi.org/10.33830/ptjj.v15i2.590.2014

Swan, K. (2003). Learning effectiveness online: What the research tells us. Elements of Quality Online Education, Practice and Direction, 4(1), 13-47.

Swan, K., Shea, P., Frederickson, E., Pickett, A. Pelz, W., \& Maher, G. (2000). Building knowledge building communities: Consistency, contact, and communication in the virtual classroom. Journal of Educational Computing Research, 23(4), 389-413. https://doi.org/10.2190\%2FW4G6-HY52-57P1-PPNE

Trigwell, K. (2001). Judging university teaching. International Journal for Academic Development, 6(1), 65-73. https://doi.org/10.1080/13601440110033698

Tsai, C. W. (2010). The effects of feedback in the implementation of web-mediated self-regulated learning. $C y$ berPsychology \& Behavior, 13(2), 153-158. https://doi.org/10.1089/cyber.2009.0267

Weller, M. (2007). The distance from isolation: Why communities are the logical conclusion in e-learning? Computers \& Education, 49, 148-159. https://doi.org/10.1016/j.compedu.2005.04.015

Wilcox, P., Winn, S., \& Fyvie-Gauld, M. (2005). 'It was nothing to do with the university, it was just the people': The role of social support in the first-year experience of higher education. Studies in Higher Education, 30(6), 707-722. https://doi.org/10.1080/03075070500340036

Wright, R., Jones, G., \& D’Alba, A. (2015). Online students' attitudes towards rapport-building traits and practices. International Journal of Innovation and Learning, 17(1), 36-58. https://doi.org/10.1504/IJIL.2015.066063

Yerby, J. (2017). An analysis of presence in an asynchronous online undergraduate mastery course using structural equation modeling [Unpublished dissertation. Georgia State University].

Zhou, Y., Jindal-Snape, D., Topping, K., \& Todman, J. (2008). Theoretical models of culture shock and adaptation in international students in higher education. Studies in Higher Education, 33(1), 63-75. https://doi.org/10.1080/03075070701794833

Zimmerman, B. J. (2001). Theories of self-regulated learning and academic achievement: An overview and analysis. In B. J. Zimmerman \& D. H. Schunk (Eds.), Self-regulated learning and academic achievement: Theoretical perspectives (2nd ed., pp. 1-37). Erlbaum.

Zimmerman, B. J. (2002). Achieving self-regulation: The trial and triumph of adolescence. In F. Pajares \& T. Urdan (Eds.), Academic motivation of adolescents (Vol. 2), (pp. 1-27). Information Age.

Zimmerman, B. J. (2008). Investigating self-regulation and motivation: Historical background, methodological developments, and future prospects. American Educational Research Journal, 45(1), 166-183.

https://doi.org/10.3102\%2F0002831207312909 


\section{AUTHORS}

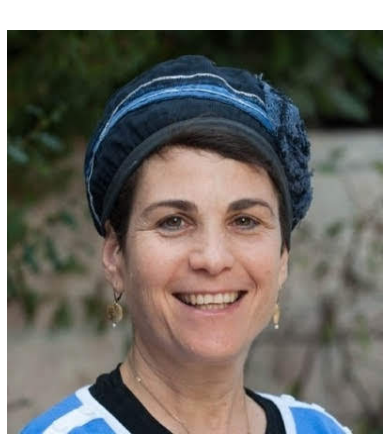

Dr. Hava Sason is the coordinator of the Department of Education and a lecturer of education and physics at the Herzog Academic College, Israel.

She holds a bachelor's degree in physics, and a master's degree and a Ph.D. in education and science teaching.

She is a researcher in the fields of self-regulated learning and the teacher's role in distance learning.

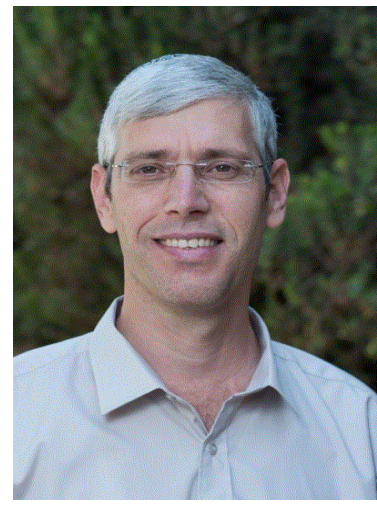

Dr. Avichai Kellerman is the Head of the Education Department and vice-rector of Herzog Academic College, Israel. He holds a PhD in education from the University of Tel Aviv.

Currently, he researches the history of education and the religious public education and works in the field of philosophy of education 